\title{
A Dynamic Approach to Grazing Management Terminology
}

\author{
DAVID L. SCARNECCHIA AND M.M. KOTHMANN
}

\begin{abstract}
Expressions such as stocking density, stocking rate, grazing pressure, herbage allowance, grazing intensity and stocking pressure have long been used to describe animal-pasture systems. These expressions describe relationships among the basic variables of animal demand, forage quantity, pasture area, and grazing duration. Our objective was to develop a dynamic, mathematical framework of expressions summarizing all of the meaningful relationships among these variables. The resulting expressions have dimensional validity, and are useful in describing dynamic animal-pasture systems. The expressions should also prove useful in future efforts to model these systems.
\end{abstract}

Efforts to describe basic quantitative relationships between grazing animals and pasture have produced numerous expressions, including stocking density, stócking rate, grazing pressure, herbage allowance, grazing intensity, stocking intensity, stocking pressure, and others (Booysen 1967, Society for Range Management 1974, Hodgson 1979).

In general, four variables are involved in describing animalpasture relationships. These variables are pasture area $(A)$, usually expressed in ha; forage dry matter (DM) usually expressed in $\mathrm{kg}$; duration of grazing $(t)$, usually expressed in days or months; and the animals' forage demand rate (D), here expressed in animalunits (au). The variable which is functionally important in describing the potential effect of the animal component on a pasture is neither animal live-weight (LW) nor animal numbers alone, but rather the animals' rate of demand for forage, which might be termed the potential rate of forage intake. The potential rate of intake is a function of animal numbers, weight, physiological state, and other animal-related factors.

\section{The Animal-Unit and the Animal-Unit Equivalent}

If we are to use the animals' demand rate for forage in describing animal-pasture systems, we must have an appropriate unit. The Society for Range Management (1974) has defined one animalunit as "one mature $454 \mathrm{~kg}$ cow or its equivalent based on an average forage consumption of $12 \mathrm{~kg}$ of dry matter per day." Here, we define an animal-unit to be a unit of animal demand rate, and to repesent an animal with a rate of demand for forage equal to $12 \mathrm{~kg}$ $\mathrm{DM} /$ day. Any animal may be represented as a certain fraction or multiple of the animal-unit, based solely on its quantitative demand rate for forage. An animal which has a demand rate more or less than $12 \mathrm{~kg} \mathrm{DM} /$ day will have an animal-unit-equivalent (aue) which is a proportionate fraction or multiple of I animalunit.

In the past, the assigning of animal-unit-equivalents to animals has usually been approximate, and was often based on liveweight $(\mathrm{LW})$ or $\mathrm{LW}^{\mathrm{it}}$. If the approach discussed in this paper is to be of maximum usefulness, accurate estimates of animal-unitequivalents are important. Standardization of estimation

\footnotetext{
Authors are assistant professor, Department of Forestry and Range Management Washingt on State University, Pullman, 99164; and professor of range science, Texas A\&M University, College Station, 77843.

This report is approved as TA-16331 from the Texas Agr. Exp. Sta., College Station, 77843 .
}

procedures is also important. Animal-unit-equivalents might be estimated using published dry matter requirements for each particular kind, class and weight of livestock like those published by the United States National Research Council (NRC) (1976). Such published data might serve as a starting point from which further refinement, based on other specific animal characteristics, could be attempted. Detailed tables and mathematical functions could be developed to quickly obtain animal-unit-equivalents based on reasonable correlates in animal characteristics. In any case, the researcher should describe in detail how animal-unitequivalents are obtained.

Within any infinitely small time interval, an animal at pasture represents a rate of forage demand on the pasture. The integration of this demand rate over a time interval $t$ represents an amount of forage demanded, i.e.,

$$
\text { Amount of Forage Demand }=\int_{t_{0}}^{t} \text { Demand Rate } \bullet \text { dt. (1) }
$$

In practice, the summation form of Equation 1 would be used;

$$
\text { Amount of Forage Demand } \left.=\sum_{i=I}^{n} \text { (Mean Demand Rate) }\right)_{i} t_{i} \text {, }
$$

where each (Mean Demand Rate) $)_{i}$ is the demand rate assigned to subperiod $t_{i}$. If a mean demand rate is assumed over the period $t$,

Amount of Forage Demand $=$ Mean Demand Rate $\bullet t$

The most common units of the quantity of animal demand are the animal-unit-day (aud), the animal-unit-month (aum), and the animal-unit-year (auy). Each unit represents an amount of forage, i.e., $1 \mathrm{aud}=12 \mathrm{~kg} \mathrm{DM}, 1 \mathrm{aum}=360 \mathrm{~kg} \mathrm{DM}$, and $1 \mathrm{auy}=4380 \mathrm{~kg}$ DM.

\section{Stocking Density and Stocking Rate}

The Society for Range Management (1974) defined stocking density as the relationship between the number of animal-units and the land area at any instant in time. The typical unit is au/ha.

Bóoysen (1976) and the Society for Range Management (1974) defined stocking rate as the number of animal-units per unit of land over a period of time. Mathematically, for a grazing period $\left(t-t_{0}\right)$,

$$
\text { Stocking Rate }=\int_{t_{0}}^{t} \text { Stocking Density } \bullet \text { dt. }
$$

In summation form,

$$
\text { Stocking Rate }=\sum_{i=1}^{n}(\text { Mean Stocking Density })_{i} \bullet \mathbf{t}_{\mathrm{i}},
$$

where each (Mean Stocking Density) is the mean stocking density of each particular subperiod $t_{i}$ making up the grazing period $t$. If a mean stock density is assumed over the grazing period $t=\Sigma t_{i}$,

$$
\text { Stocking Rate }=\text { Mean Stocking Density } \bullet t \text {. }
$$

Units of stocking rate must be in terms of an amount of forage demand per unit area, typically aud/ha, aum/ha or auy/ha. The 
annual stocking rate within a pasture is the sum of the stocking rates of individual grazing periods within a year, i.e,

$$
\text { Annual Pasture Stocking Rate }=\underset{\mathrm{f}=\mathrm{i}}{\mathrm{m}} \text { (Stocking Rate) }
$$

where $m$ is the number of grazing periods within a year. An annual pasture stocking rate can have units of aud/ha, aum/ha or auy/ha.

Since complex grazing systems are becoming increasingly common, it is often useful to express the stocking rate of a number of pastures managed under a grazing system. The stocking rate for an entire grazing system can be expressed as

System Stocking Rate $=\int_{t_{0}}^{t} \frac{(\text { Animal Demand Rate })}{\text { Total System Area }} \cdot d(8)$ or in summation form as

System Stocking Rate $=\sum_{i=1} \frac{(\text { Mean Animal Demand Rate })_{i}}{\text { Total System Area }} t_{i}$, (9) $\Sigma \mathrm{t}_{\mathrm{i}}$,

where $p$ is the number of pastures in the system, and each (Mean Animal Demand Rate) is the mean number of animal-units within each calculation period $i$. The system stocking rate is usually of interest on an annual basis, and for clarity, the term annual system stocking rate should be used when the annual rate is being described. When system stocking rates are calculated, for example, monthly then

Annual System Stocking Rate $=\underset{i=1}{n}$ Monthly System Stocking

Typical units for both system stocking rate and annual system stocking rate are also aud/ha, aum/ha, auy/ha.

\section{Grazing Pressure and Grazing Pressure Index}

The Society for Range Management (1974) defines grazing pressure as the animal-to-forage ratio at a given instant. Grazing pressure, like stocking density, is defined at any instant, and thus its units have no time dimension. Typical units are $\mathrm{au} / \mathrm{kg}$ and au/ton.

The integration over time of grazing pressure yields a meaningful, though previously undescribed expression, the grazing pressure index. Thus, mathematically,

$$
\text { Grazing Pressure Index }=\int_{t_{0}}^{t} \text { Grazing Pressure • dt. }
$$

In summation form,

Grazing Pressure Index $=\sum_{i=1}^{n}$ (Mean Grazing Pressure $)_{i} \bullet t_{i}$.

If a mean grazing pressure is assumed over the grazing period $\mathrm{t}=$

Grazing Pressure Index $=$ Mean Grazing Pressure $\bullet t$.

That the grazing pressure index is in fact an index can be seen by recalling that the product of a demand rate and a time period is equivalent to an amount of forage. Values of the grazing pressure index can range from zero to infinity, but most actual grazing situations will have grazing pressure indices between zero and one. This index is the integrated animal demand/forage supply ratio over a time period.

\section{The Herbage Allowance and Cumulative Herbage Allowance}

While grazing pressure expresses the ratio of animal demand to forage weight at any instant, the inverse of this ratio, the herbage allowance, expresses the ratio of the weight of forage available to

Table 1. Summary of relationships among the variable of animal demand, forage quality, pasture area, and time. 1 au $=1$ animal unit $=12 \mathrm{~kg}$ forage $/ \mathrm{day}$

\begin{tabular}{|c|c|c|}
\hline Animal/Area & Animal/Forage & Forage/Animal \\
\hline Stocking Rate & Grazing Pressure Index & Cumulative Herbage Allowar \\
\hline $\begin{array}{l}=\int_{\mathrm{t}_{0}}^{\mathrm{t}} \text { stocking density } \cdot \mathrm{dt} \\
\text { Units: aud } / \text { ha } \\
\text { aum } / \text { ha }\end{array}$ & $\begin{array}{l}=\int_{t_{0}}^{t} \text { graz. pressure } \cdot d t \\
\text { Units: Ratio of animal demand } \\
\text { to forage over a period of time }\end{array}$ & $\begin{array}{l}=\int_{t_{0}}^{t} \text { herb. allowance } \bullet d t \\
\text { Units: } k g-\text { days } / a u \\
\text { tons - months } / a u\end{array}$ \\
\hline Stocking Density & Grazing Pressure & Herbage Allowance \\
\hline$=\underset{\text { instant }}{\text { Animal demand per unit area at any }}$ & $\begin{array}{l}=\text { animal demand per unit weight } \\
\text { of forage at any instant }\end{array}$ & $\begin{array}{l}=\text { weight of forage per unit } \\
\text { animal demand at any inst }\end{array}$ \\
\hline Units: au/ha & $\begin{array}{r}\text { Units: } \mathrm{au} / \mathbf{k g} \\
\mathrm{au} / \mathrm{ton}\end{array}$ & $\begin{array}{r}\text { Units: } \mathrm{kg} / \mathrm{au} \\
\mathrm{ton} / \mathrm{au}\end{array}$ \\
\hline- & & \\
\hline Rate of Change in Stocking Density & $\begin{array}{l}\text { Rate of Change in Grazing } \\
\text { Pressure }\end{array}$ & $\begin{array}{l}\text { Rate of Change in Herbage } \\
\text { Allowance }\end{array}$ \\
\hline$=\mathrm{d}($ stocking density) & $=\mathrm{d}$ (grazing pressure) & $=\mathrm{d}($ herbage allowance $)$ \\
\hline $\mathrm{dt}$ & $\mathrm{dt}$ & $d t$ \\
\hline $\begin{array}{r}\text { Units: au/ha/day } \\
\text { au/ha/hr }\end{array}$ & $\begin{array}{l}\text { Units: } \mathrm{au} / \mathbf{k g} / \text { day } \\
\mathrm{au} / \mathbf{k g} / \mathbf{h r} \\
\text { etc. }\end{array}$ & $\begin{array}{l}\text { Units: } \mathrm{kg} / \mathrm{au} / \mathrm{day} \\
\mathrm{kg} / \mathbf{a u} / \mathrm{hr} \\
\text { etc. }\end{array}$ \\
\hline
\end{tabular}
in animal demand.

Forage/Area
Standing Crop
= weight of forage standing per unit
area at any instant
Units: $\mathrm{kg} / \mathrm{ha}$
$\mathrm{g} / \mathrm{m}^{2}$

Net Forage Accumulation Rate

$=\frac{\mathrm{d}(\text { standing crop) }}{\mathrm{dt}}$

Units: $\mathrm{kg} / \mathrm{ha} /$ day

$\mathrm{kg} / \mathrm{ha} / \mathrm{hr}$

etc.

Rate of Change in Net Forage Accumulation Rate

$=\mathrm{d}$ (net forage acc. rate) $\mathrm{dt}$

Units: $\mathrm{kg} / \mathrm{ha} / \mathrm{hr}^{2}$

$\mathbf{k g} /$ ha-day ${ }^{2}$ 
the amount of animal demand. Thus, the animal demand-to-forage relationship in a pasture at any time can be expressed either as a grazing pressure or as an herbage allowance. A typical unit of herbage allowance is tons/au.

Just as the integration over time of grazing pressure yields a grazing pressure index, the integration of herbage allowance yields an analogous expression, the cumulative herbage allowance. Mathematically,

$\underset{\text { Allowance }}{\text { Cumulative Herbage }}=\int_{\mathrm{t}_{0}}^{\mathrm{t}}$ Herbage Allowance $\cdot \mathrm{dt}$.

In summation form,

$$
\begin{aligned}
& \text { Cumulative Herbage } \\
& \text { Allowance }
\end{aligned}=\sum_{i=1}^{n}(\text { Mean Herbage Allowance })_{i} \bullet t_{i} \text {. }
$$

If a mean herbage allowance is assumed over the time period $t=$ $\Sigma t_{i}$,

Cumulative Herbage $=$ Mean Herbage Allowance $\bullet t$.

Allowance

The cumulative herbage allowance expresses the relationship between forage supply and animal demand over a time period, and has typical units of $\mathrm{kg}$ - days/au or ton - months/au.

\section{Other Useful Relationships}

If stocking density is differentiated with respect to time, the result is an expression describing the rate of change in stocking density. The change can be expressed as

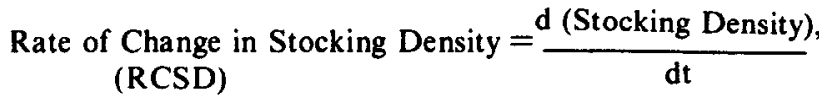

or in discrete form as,

$$
\mathrm{RCSD}=\frac{\Delta \text { Stocking Density. }}{\Delta \mathrm{t}}
$$

The RCSD has units of au/ha/hr, or au/ha/day. Within a pasture of fixed area, a change in the stocking density could be the result of (1) the addition or removal of livestock by the grazing manager, or (2) a change in the animal-unit-equivalents of the animals already present, corresponding to a change in the potential dry-matter intake per animal.

An expression analogous to the RCSD is obtained if grazing pressure is differentiated with respect to time. Mathematically,

$$
\begin{aligned}
& \text { Rate of Change in Grazing Pressure }=\frac{d \text { (Grazing Pressure) }}{\text { (RCGP) }} \\
& \text { (Rt }
\end{aligned}
$$

In discrete form,

$$
\mathrm{RCGP}=\Delta \text { Grazing Pressure, }
$$$$
\Delta \mathrm{t}
$$

and typical units for RCGP are au/ $\mathrm{kg} / \mathrm{day}$ or $\mathrm{au} / \mathrm{ton} / \mathrm{day}$. A change in the grazing pressure can result either from changes in the number of animal-units in a pasture or from a change in the amount of forage available. Two analogous expressions exist describing the rate of change in herbage allowance (RCHA) with respect to time.

\section{Forage-Area Relationships}

Describing the behavior of animal-pasture systems accurately requires expressions which describe the dynamic nature of the forage component. At any instant, an amount of standing plan material is present in a pasture. This standing forage is termed the standing crop, and is usually described on a per unit area basis with typical units of $\mathrm{kg} \mathrm{DM} / \mathrm{ha}$ or $\mathrm{g} \mathrm{DM} / \mathrm{m}^{2}$.

Standing crop is usually constantly changing. If standing crop is differentiated with respect to time, an expression of the rate of change in the standing crop is obtained,i.e.,

$$
\begin{aligned}
& \text { Net Forage Accumulation Rate } \\
& \text { (NFAR) }
\end{aligned}
$$

In discrete form,

$$
\text { NFAR }=\frac{\Delta \text { Standing Crop. }}{\Delta \mathrm{t}}
$$

dt

The NFAR has units of $\mathrm{kg} \mathrm{DM} / \mathrm{ha} / \mathrm{hr}$, or $\mathrm{kg} \mathrm{DM} / \mathrm{ha} /$ day, and describes the net addition to or subtraction from the standing crop due to the combined effects of forage production, animal intake, weathering losses, etc.

Differentiation of NFAR results in an expression of the rate of change in the net forage accumulation rate, i.e.,

$$
\text { Rate of Change in NFAR }=\frac{d(N F A R)}{d t}
$$

In descrete form,

$$
\mathrm{RCNFAR}=\frac{\Delta \mathrm{NFAR}}{\Delta \mathrm{t}}
$$

The RCNFAR with typical units of $\mathrm{kg} \mathrm{DM} / \mathrm{ha}-\mathrm{min}^{2}$, $\mathrm{kg} \mathrm{DM} / \mathrm{ha}$ $\mathrm{hr}^{2}$, or $\mathrm{kg} \mathrm{DM} /$ ha-day ${ }^{2}$ describes changes in the net rate of forage accumulation. These changes can result from changes in plant growth rates, changes in animal demand rates, changes in the rate of weathering losses, etc.

\section{Summary of the Expressions Describing Animal-Pasture Systems}

The expressions of relationships between animal demand, forage, area, and time are summarized in Table 1.

\section{Expressing Animal Production}

It is possible to express animal production as animal liveweight gain per amount of animal demand, i.e., as $\mathrm{kg} \mathrm{LW/aud,} \mathrm{kg}$ $\mathrm{LW} / \mathrm{aum}$, or $\mathrm{kg} \mathrm{LW} / \mathrm{auy}$. However, since the number of animalunits in a pasture is usually changing, animal production generally should not be expressed in units of $\mathrm{kg} \mathrm{LW} / \mathrm{au}$ or $\mathrm{g} \mathrm{LW} / \mathrm{au}$.

\section{Conclusions}

Describing animal-pasture systems requires the use of dynamic variables and expressions. The animal demand variable, with units of a nimal-units, is useful in describing these systems. The dynamic framework of expressions offered here describes the relationships among the variables of animal demand, forage quantity, area, and duration of grazing. This approach should prove useful in the refinement of future grazing research and management, and in future attempts to model animal-pasture systems.

\section{Literature Cited}

Booysen, P. De V. 1967. Grazing and grazing management terminology ir South Africa. Proc. Grassld. Soc. Sth. Afr. 2:45-57.

Hodgson, J. 1979. Nomenclature and definitions in grazing studies. Grass and Forage Sci. 34:11-18.

National Research Council. National Academy of Sciences. Subcommittee on Beef Cattle Nutrition. 1976. Nutrient requirements of beef cattle, 5th ed.

Society for Range Management. 1974. A glossary of terms used in range management. 2nd ed. 